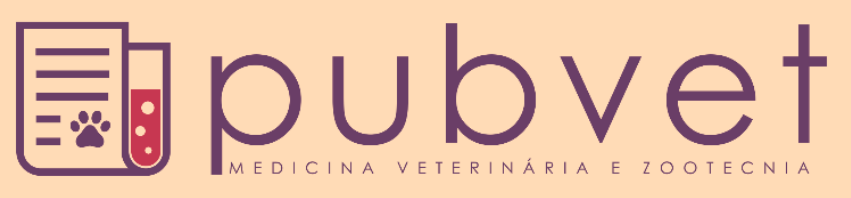

https://doi.org/10.31533/pubvet.v13n7a372.1-18

\title{
Alterações genéticas envolvidas na expressão das pelagens tortoiseshell e cálico em gatos domésticos machos: Revisão
}

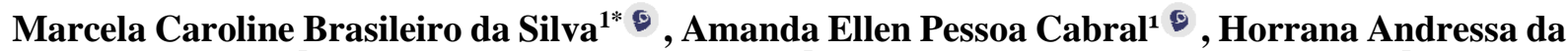 \\ Silva Rodrigues ${ }^{\ominus}$, Caoan Iuri de Brito Silva ${ }^{\ominus}$, Dominique Oliveira Cavalcante ${ }^{1}{ }^{\ominus}$, Rayssa \\ Kuster Klabunde $^{1} \odot$, Ividy Bison ${ }^{1}$, Igor Mansur Muniz ${ }^{2}$ \\ ${ }^{I}$ Acadêmico da Universidade Federal de Rondônia, Departamento de Medicina Veterinária. Rolim de Moura -RO Brasil. \\ ${ }^{2}$ Professor da Universidade Federal de Rondônia, Departamento de Medicina Veterinária. Rolim de Moura-RO Brasil.E-mail: igor.mansur@ unir.br \\ *Autor para correspondência, E-mail: marcela.brasileiro@hotmail.com
}

Resumo. Os mamíferos possuem conjunto cromossômico diploide, em que metade corresponde ao material genético herdado do pai, e a outra metade da mãe. Gatos domésticos (Felis catus) possuem número diploide de 38 cromossomos, sendo dois deles os cromossomos sexuais, responsáveis pela determinação do sexo, e que são representados por X e Y. As fêmeas possuem cromossomos sexuais XX, e os machos XY. As pelagens tortoiseshell e cálico podem estar presentes em gatos e são determinadas pela presença das cores preta e laranja em um mesmo animal, só que distribuídas de formas diferentes ao longo do corpo. Fisiologicamente, essas duas pelagens só podem ser observadas em fêmeas. Laranja e preto são cores determinadas pelo cromossomo X, portanto, conclui-se que essas duas cores só podem ser expressas em um mesmo animal, quando se trata de fêmeas, pois as mesmas possuem dois cromossomos X. Alguns machos nascem tortoiseshell ou cálico devido à ocorrência de anomalias cromossômicas, sendo a mais comum a anomalia semelhante à Síndrome de Klinefelter em humanos (47,XXY), que em gatos é 39,XXY. Essa condição é rara em machos, e para diagnóstico definitivo, o cariótipo é o exame citogenético mais utilizado. O trabalho teve por objetivo destacar as alterações genéticas envolvidas na presença das colorações das pelagens tortoiseshell e cálico em gatos domésticos machos, e o estudo tem importância na clínica veterinária de pequenos animais, já que essas desordens genéticas, em sua maioria, provocam distúrbios reprodutivos. A revisão tem significativa relevância na atuação do Médico Veterinário na área de citogenética clínica em pequenos animais, bem como no desenvolvimento de estudos voltados à área, que são consideravelmente escassos.

Palavras chave: anomalia, cariótipo, citogenética, cromossomos

\section{Genetic alterations involved in the expression of the coloring of tortoiseshell and calcial hair in domestic cats males: Review}

Abstract. The mammals have a diploid chromosomal group, in which half correspond to
the genetic material inherited by their father, and the other half by their mother. Domestic
cats (felis catus) have number diploid of 38 chromosomes, two of them are the sexual
chromosomes, represented by X and Y, who are responsible for the determination of the
sex. Calicos and tortoiseshell's coats may be present in cats and are determined by the
presence of the colors black and orange in the same animal, but distributed in different
forms along the body. Physiologically, these two coats can only be observed in females.
Orange and black are determined by chromosome X, therefore, these two colors can only
be present in the same animal when it's a female, because it has two chromosomes X. Some
males are born tortoiseshell or calic because of chromosomal abnormalities. The most 
common one is similar to the Klinefelter Syndrome in humans (47, XXY), which in cats is $39, \mathrm{XXY}$. This condition is rare in males, and for definitive diagnosis, karyotype is the most commonly used cytogenetic exam. This work aims to highlight the genetic alterations involved in the presence of tortoiseshell and calic's coats in domestic male cats, and the study is important in small animals veterinary clinics, since these genetic disorders, mostly, cause reproductive disturbances. The review has significant relevance to the veterinarian performance in the area of cytogenetic clinic in small animals, as well as in the development of studies dedicated to this area, which are considerably rare.

Keywords: anomaly, karyotype, cytogenetic, chromosomes

\section{Alteraciones genéticas relacionadas con la expresión de pelajes carey y calico en gatos machos domésticos: Revisión}

Resumen. Mamíferos poseen conjunto cromosómico diploide, en el que un medio corresponde al material genético heredado del padre, y la otra mitad de la madre. Los gatos domésticos (Felis catus) tienen número diploide de 38 cromosomas, dos de los cromosomas sexuales, responsables de la determinación del sexo, y que están representados por X e Y. Las hembras tienen cromosomas sexuales XX y los machos XY. Los pelos carey y calico pueden estar presentes en los gatos y son determinados por las presencias de colores negras y naranja en el mismo animal, solamente distribuidas en diferentes maneras a lo largo del cuerpo. Fisiológicamente, estos dos tipos de pelo sólo pueden ser observados en las hembras. Los colores naranja y negro son determinados por el cromosoma X, por lo que se concluye que estos dos colores se pueden expresar en el mismo animal cuando se trata de hembras, porque tienen dos cromosomas X. Algunos machos nacen con pelo carey o calico debido a la aparición de anormalidades cromosómicas, siendo la más común la anomalía similar al síndrome de Klinefelter en los seres humanos (47, XXY), que en los gatos es de 39, XXY. Esta condición es poco común en machos, y para diagnóstico definitivo, el cariotipo es el examen citogenético más común. El estudio tuvo como objetivo poner de relieve las alteraciones genéticas implicadas en la presencia de pelos carey y calico en los gatos machos domésticos, y el estudio es importante en la clínica veterinaria para pequeños animales, ya que estos trastornos genéticos, en su mayoría causa trastornos reproductivos. La revisión tiene una relevancia significativa en el papel del veterinario en el área de la citogenética clínica en pequeños animales, así como en el desarrollo de estudios enfocados al área.

Palabras-clave: anomalía citogenética cariotipo, cromosomas

\section{Introdução}

Gatos domésticos podem expressar diferentes tipos de pelagens. As pelagens tortoiseshell ou cálico podem ser expressas por fêmeas. A pelagem tortoiseshell, popularmente conhecida como "casco de tartaruga" ou "escaminha" é caracterizada pela presença dos pelos pretos mesclada com pelos laranja ao longo de todo o corpo do animal. Na pelagem cálico, conhecida também como tricolor, as cores preto, laranja e branco apresentam-se de forma independente. A semelhança entre ambas é a presença das cores preta e laranja em um único animal.

Fisiologicamente, as colorações de pelagem tortoiseshell e cálico só podem ser expressas em gatas, por elas possuírem os cromossomos sexuais XX, ao passo que os dos machos são XY. O cromossomo $\mathrm{X}$ é responsável pela expressão das cores laranja e preto. Quando esse fenômeno ocorre em gatos machos, que, por sua vez, apresentam um cromossomo sexual X, é resultado de anomalias presentes nos cromossomos sexuais, que podem ser Síndrome de Klinefelter (39, XXY), mosaicismo ou quimerismo.

É preciso haver entendimento acerca da ocorrência dessas pelagens em macho, tendo em vista que muitos profissionais desconhecem a existência dessas desordens genéticas. O diagnóstico dessas alterações é relevante, já que a maioria delas causa distúrbios reprodutivos nos animais, comprometendo sua fertilidade e, em alguns casos, os deixando mais predispostos ao desenvolvimento de algumas 
patologias do sistema reprodutor. A revisão teve por objetivo destacar as alterações genéticas que promovem a expressão das pelagens tortoiseshell e cálico em gatos domésticos machos.

\section{Introdução à genética}

O monge austríaco Gregor Mendel iniciou os estudos voltados à Genética quando em 1865 tornou público os resultados referentes ao cruzamento de ervilhas, e deduziu que diferentes fatores levavam as informações dos genitores sobre a prole, muito embora essa descoberta não tenha sido reconhecida por outros cientistas de imediato (Griffiths et al., 2008). Logo após o reconhecimento das leis de Mendel, Archibald Garrot em 1902 foi um dos fundadores da genética médica, e um ano mais tarde, Sutton e Boveri, analisando como os cromossomos agiam durante a divisão celular, concluíram que os genes estariam contidos nos cromossomos. O termo "genética" foi designado em 1906 pelo biólogo William Bateson e em 1909 Wilhelm Johannsen, um botânico dinamarquês criou o termo "gene" para designar os fatores de natureza hereditária destacados por Mendel. Na década de 1940 houve a determinação de que os genes são compostos por ácido desoxirribonucleico (DNA). Em 1962, James Watson e Francis Crick ganharam o prêmio Nobel por descreverem a estrutura molecular do DNA em 1953. A genética molecular envolveu descobertas como o estabelecimento de que o DNA é transcrito para ácido ribonucleico (RNA), que por sua vez é traduzido em proteína, e o que determina a sequência dos aminoácidos na proteína é a decifração do código genético (Borges-Osório \& Robinson, 2013; Griffiths et al., 2008).

A genética é a ciência que estuda a estrutura e função dos ácidos nucleicos, o DNA e RNA. A universalidade do DNA facilita o estudo dessa ciência, bem como as características hereditárias dos organismos vivos e expressões das mesmas. As características hereditárias dos organismos vivos estão codificadas no DNA. Esse DNA apresenta-se na sequência de nucleotídeos, que por sua vez, são as unidades básicas dos ácidos nucleicos, ligados de modo semelhante a elos de uma corrente, formando longas moléculas. Na maioria dos organismos eucariotos o DNA é formado por duas fitas complementares destas ligações de nucleotídeos em forma de uma espiral. Essa disposição é denominada dupla hélice. A dupla hélice é disposta com proteínas no núcleo da célula eucariótica, e forma um cromossomo. O número de cromossomos varia de organismo para organismo (Pazza \& Kavalco, 2015). A maioria dos seres vivos possuem cromossomos diploides. O termo "diploide" é utilizado para determinar organismos que possuem dois lotes cromossômicos, sendo eles um da mãe, e um do pai, e os mamíferos, em sua maioria, possuem essa característica (Pazza \& Kavalco, 2015). O número básico de cromossomos de uma espécie é denominado haploide, podendo ser representado pela letra "n" (Junqueira \& Carneiro, 1997). Genes são designados como as sequências de nucleotídeos em uma molécula de DNA responsáveis por características tanto micro, quanto macroscópicas, como alguma proteína, ou determinação da cor do olho ou pelo, respectivamente (Pazza \& Kavalco, 2015). Os genes estão presentes nos cromossomos que, quando localizados em células reprodutivas, passam as informações genéticas para a próxima geração. Os seres humanos possuem 22 pares de cromossomos autossômicos, e um par de cromossomos sexuais (XX em mulheres e XY em homens) (Ramos \& Cunha, 2016). O local específico que um gene ocupa em um cromossomo, é chamado lócus. Vale destacar que um único cromossomo pode possuir diversos loci (Pazza \& Kavalco, 2015).

Após o desenvolvimento de estudos voltados à morfologia dos cromossomos, pesquisadores descobriram que há dois exemplares iguais de cada um por célula diploide. Então, existem pares de cromossomos nos núcleos que são chamados homólogos (Junqueira \& Carneiro, 1997). Par de cromossomos homólogos é o nome dado a organismos diploides que possuem o lote cromossômico do pai e o outro da mãe. Cromossomos constituintes de um par de homólogos possuem a mesma região para um determinado gene, que podem ser de sequências iguais ou diferentes. Cada sequência nestes loci é denominada alelo. Alelos são formas alternativas de genes, que estão presentes em um determinado lócus de um dos cromossomos do par de homólogos (Figura 1). Um conjunto de alelos de determinada característica é denominado genótipo. É importante destacar que todos os lócus podem possuir apenas dois alelos em cada indivíduo, já que um alelo veio do pai, e outro da mãe (Pazza \& Kavalco, 2015).

Então, determina-se que cada característica originária de um gene pode possuir até dois alelos em todos os lócus, sendo um alelo do pai, e o outro da mãe. Se esses dois alelos são iguais, o determinado indivíduo é denominado homozigoto para a característica. Se forem diferentes, o indivíduo é heterozigoto para a característica (Pazza \& Kavalco, 2015). 


\section{Genes, alelos e cromossomos}

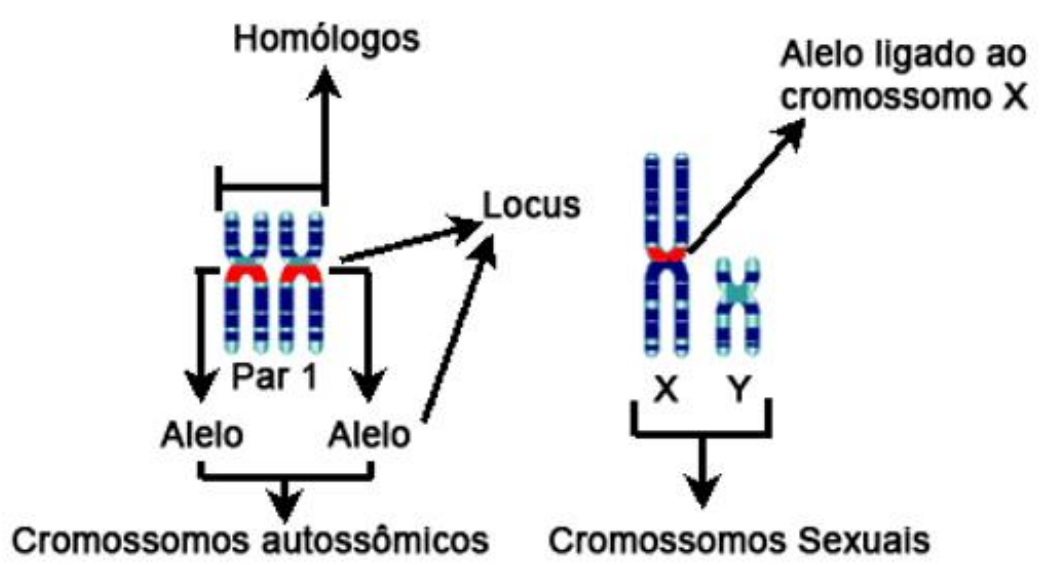

Figura 1. Em cada par cromossômico há lócus para o mesmo gene, e cada cromossomo possui uma cópia do gene, denominado alelo. Fonte: Pazza \& Kavalco (2015).

Mendel estabeleceu a lei da dominância, que determina que em seres heterozigotos, uma característica é ocultada por outra por meio de alelos. O alelo dominante será expresso, ao passo que o alelo recessivo permanece "latente", porém, ambos serão transmitidos aos descendentes. Ainda assim, o alelo recessivo poderá ser expresso, mas só quando há a presença de duas cópias do mesmo (Rye et al., 2017).

Utilizando o exemplo do comprimento de pelos em gatos, característica determinada por um gene autossômico (L/l), os pelos curtos são dominantes, então, basta a presença de um alelo dominante para que os pelos nasçam curtos (homozigoto L/L; heterozigoto L/l), logo, gatos de pelos longos são homozigotos para o alelo recessivo (1). Normalmente, o alelo dominante é representado por uma letra maiúscula, ao passo que, um alelo recessivo, uma letra minúscula (Pazza \& Kavalco, 2015). O conjunto de todos os genes é denominado genoma. A genética é uma ciência que abrange a diversidade, replicação, mutação e tradução das informações contidas no gene (Griffiths et al., 2008).

Também foi descoberto, de forma eventual, que um único gene poderia controlar verdadeiros complexos de caracteres; e esse mecanismo foi denominado pleiotropia. Casos em que mais caracteres são controlados por efeitos combinados de diversos genes são denominados epistasia. Então, um gene pode modificar a expressão fenotípica de outro gene não alélico, fenômeno conhecido como interações epistáticas (Raven et al., 1996).

A meiose é uma divisão celular que ocorre apenas em células diploides. Na meiose, uma única célula diploide dá origem à quatro células haploides, sendo estas denominadas gametas. O gameta é uma célula que se une a outro gameta para originar um zigoto diploide. A meiose é dividida em duas partes, sendo a primeira conhecida como reducional, por gerar, a partir de uma célula diploide, duas haploides; e a segunda é caracterizada como equacional, por originar, a partir dessas duas células haploides, outras quatro (Raven et al., 1996).

Há um par de cromossomos com morfologia diferente em um dos sexos na maioria das espécies que possuem sexos separados. Esses cromossomos são denominados cromossomos sexuais, e os demais são conhecidos como autossomos. Em quase todos os mamíferos, os machos possuem os cromossomos sexuais morfologicamente distintos, sendo chamados de heterogaméticos. As fêmeas, homogaméticas, possuem, em sua maioria, cromossomos sexuais semelhantes (Junqueira \& Carneiro, 1997). Em mamíferos, o sistema de cromossomos sexuais é o XY. A presença ou ausência do cromossomo Y que determina o sexo da prole, podendo ser macho ou fêmea, respectivamente. (Graves, 1995).

\section{Inativação do X/Hipótese de Lyon}

Tendo em vista que a maioria das fêmeas possuem dois exemplares do cromossomo $\mathrm{X}$, e machos possuem apenas um, há mecanismos de compensação de dose que ocorrem e são estabelecidos de formas diferentes em diferentes espécies. Na mosca-das-frutas, o cromossomo $\mathrm{X}$ do macho mostra-se hiperativado, fazendo com que o macho tenha uma dosagem do $\mathrm{X}$ equivalente ao da fêmea. Em 
mamíferos, não importa quantos cromossomos $\mathrm{X}$ a fêmea tenha, apenas um será transcricionalmente ativo. Essa compensação de dose em mamíferos é explicada por meio do mecanismo de inativação do X (Griffiths et al., 2008).

O primeiro estudo registrado sobre a inativação do X ocorreu em 1949, quando Barr e Bertram descreveram uma estrutura nuclear que se mostrava marcada fortemente em células neurais de gatas. Após alguns anos, algumas outras evidências foram notadas, como o fato de indivíduos com a Síndrome de Klinefelter (47, XXY) apresentarem fenótipo masculino, ainda que possuíssem dois cromossomos X (Jacobs \& Strong, 1959). As pesquisas iniciais foram realizadas com células de gatos fêmeas e Barr e Bertram observaram que nessas células havia uma estrutura altamente condensada (Figura 2.A) que não era observada em células de gatos machos (Figura 2.B), em que eles especularam que seria um dos cromossomos X. Posteriormente, nomearam a estrutura como corpúsculo de Barr (Figura 2.A) e outras pesquisas foram desenvolvidos, confirmando que a estrutura condensada de fato se tratava de um dos cromossomos sexuais da fêmea. Mary Lyon, em 1961, a partir de observações realizadas em células de camundongos, concluiu que o corpúsculo de Barr se tratava de um cromossomo X que sofria inativação na fase de desenvolvimento embrionário de fêmeas (Nicholas, 2010)
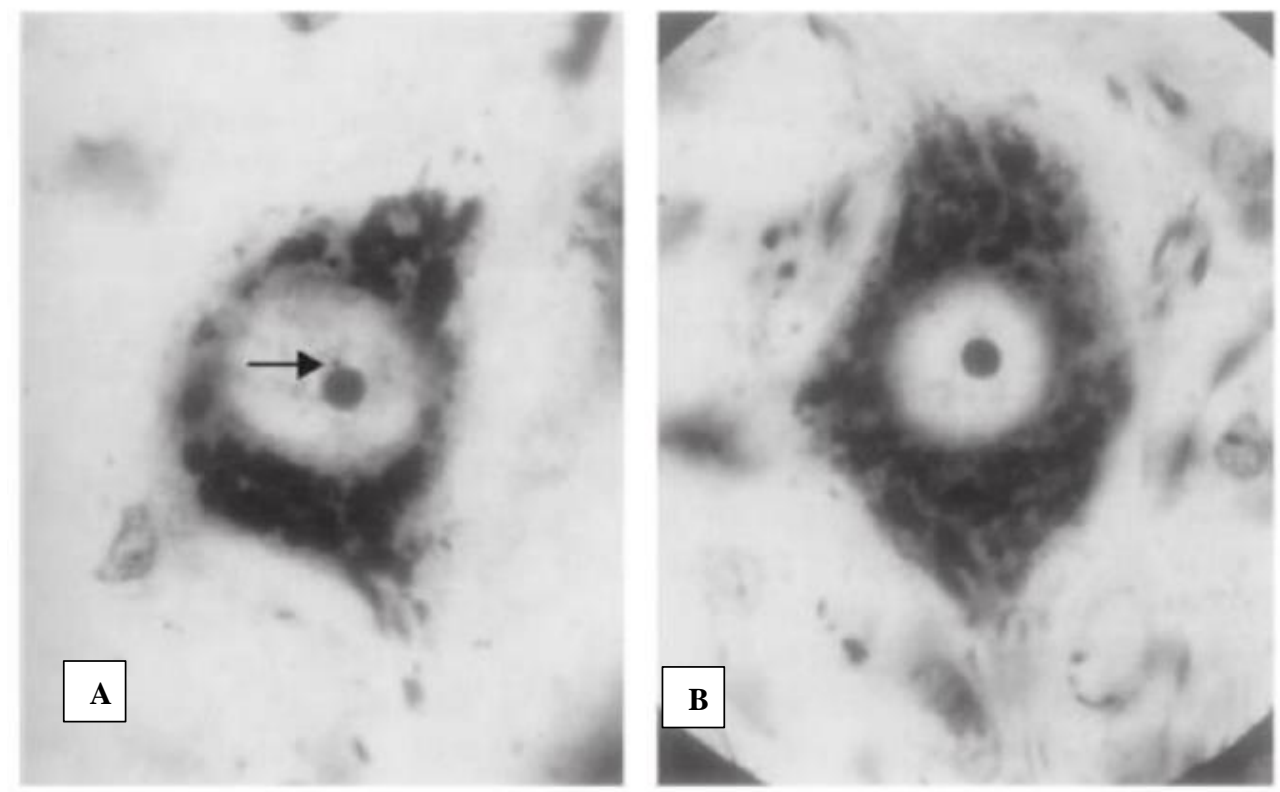

Figura 2. Células de gatos fêmea e macho. A. Núcleo celular de nervo hipoglosso de gata com a presença do Corpúsculo de Barr (seta). B. Núcleo celular de nervo hipoglosso de gato macho. Fonte: Nicholas (2010).

Quatro geneticistas, sendo eles Mary Lyon, Lianne Russell, Ernest Beutler e Susumo Ohno realizaram, independentemente, estudos sobre o mecanismo envolvido na compensação de dose do cromossomo X que, posteriormente, ficou conhecido como hipótese de Lyon (Borges-Osório \& Robinson, 2013; Lyon, 1961).

Ao contrário de fêmeas, que possuem um cromossomo $\mathrm{X}$ do pai, e um da mãe, os machos possuem apenas um cromossomo $X$ da mãe. Em fêmeas, essa dosagem de genes proveniente de dois cromossomos $\mathrm{X}$ é equilibrada devido a inativação de quase todo o material genético de um dos cromossomos X (Lyon, 1961). Lyon concluiu que nem todos os genes presentes no cromossomo inativado seriam inativos. Ou seja, os genes dentro e próximos da região pseudo-autossomal seriam funcionais (Nicholas, 2010). Esses cromossomos que são inativados permanecem empacotados, e resulta em uma forma da cromatina que é denominada heterocromatina. Como o cromossomo X não é inativado por completo, a cromatina restante, que não permanece condensada durante o período de intérfase, é denominada eucromatina. Essa heterocromatina condensada bloqueia a transcrição, fazendo com que seja inibida a expressão dos genes acerca da região heterocromática (Raven et al., 1996). O que ocorre, é que o fenótipo masculino depende da presença de um único cromossomo $\mathrm{X}$, que por sua vez, deve ser sempre ativo. 
Em fêmeas ocorre de maneira diferente. As mulheres possuem dois cromossomos sexuais X, e essa atividade de expressão precisa ser equilibrada. Logo, na maioria dos mamíferos, a inativação do cromossomo $\mathrm{X}$ controla o desequilíbrio genético de números de cromossomos $\mathrm{X}$ diferentes entre sexos (Lyon, 1961).

Essa inativação ocorre de forma aleatória, ou seja, o X inativado pode ser materno ou paterno. Essa inativação é mantida nas próximas divisões celulares, ou seja, se uma determinada célula inativa o X materno, as células subsequentes inativarão o mesmo X materno (Pazza \& Kavalco, 2015). Esse fenômeno torna a fêmea um mosaico de células em que ou um ou outro cromossomo X encontra-se ativo. A inativação do cromossomo $\mathrm{X}$ também é um fenômeno que explica por que no humano triplo $\mathrm{X}$ (XXX) não possuem muitas alterações fenotípicas. Isso ocorre pelo fato de que, apesar dos três cromossomos $\mathrm{X}$ estarem presentes, apenas um será ativo. O que explica também o fato de indivíduos XXY serem afetados de forma moderada, pois há questionamentos acerca da Síndrome de Klinefelter (XXY), em que a inativação do $\mathrm{X}$, teoricamente, deveria balancear a dose do cromossomo $\mathrm{X}$, promovendo um cariótipo de macho normal (XY), já que em mamíferos, independentemente de quantos cromossomos $\mathrm{X}$ o indivíduo tenha, eles sempre serão inativados de modo que apenas um permaneça. A explicação para esse questionamento é que, embora um $X$ seja inativado, alguns genes poderão ser transcritos, e conclui-se que isso tenha um considerável efeito em homens com características fenotípicas femininas (Griffiths et al., 2008).

A inativação aleatória do cromossomo X tem importância na determinação de algumas cores de pelagens em gatas. No início do desenvolvimento das fêmeas de mamíferos, um dos cromossomos $\mathrm{X}$ sofre inativação aleatória, produzindo inativação do X paterno em um determinado local, e inativação do X materno em outro, resultando em um mosaico de células (Griffiths et al., 2008; Pazza \& Kavalco, 2015). Essa inativação é iniciada por um gene chamado XIST ( $X$ inactivation specific transcript) e o mecanismo exato desse gene ainda são pouco conhecidos, mas o que se sabe é que, na ausência dele, a inativação do X não ocorre. Também vale mencionar que, embora a inativação do X seja um fenômeno que ocorre de forma aleatória, na ocorrência de cromossomos anormais, estes são inativados (BorgesOsório \& Robinson, 2013).

\section{Mosaicismo fenotípico como consequência da inativação do $X$}

Dentre as principais consequências clínicas e genéticas envolvidas na inativação do cromossomo X, destaca-se em gatas tortoiseshell ou cálico, o mosaicismo. As fêmeas de mamíferos, em geral, possuem duas populações de células, em que os dois cromossomos X são inativados, mas em locais diferentes ao longo do corpo, sendo considerados mosaicos para os genes presentes no cromossomo X. Um exemplo perceptível a ser mencionado em mulheres mosaicas é a displasia ectodérmica hipoidrótica, em que mulheres portadoras desse gene têm áreas da pele sem glândulas sudoríparas e pelos, como é possível observar na figura 3 (Borges-Osório \& Robinson, 2013).

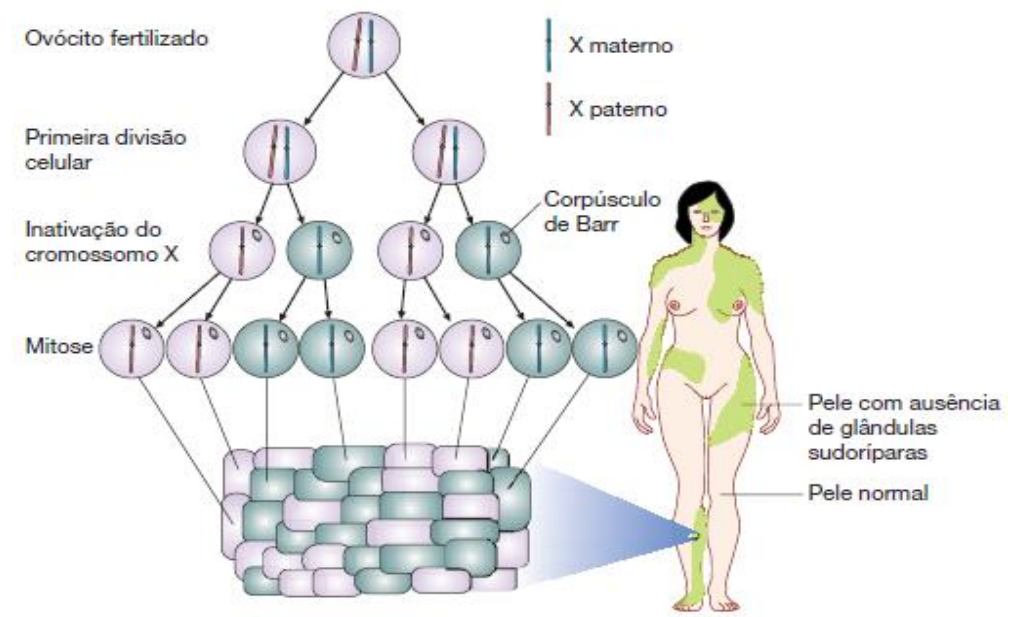

Figura 3. Mosaicismo fenotípico resultante da inativação do X. Na displasia ectodérmica hipoidrótica, a mulher tem áreas da pele sem glândulas sudoríparas e pelos. Fonte: Borges-Osório \& Robinson (2013). 
O padrão tortoiseshell também é uma importante evidência para a hipótese de Lyon, já que fêmeas heterozigotas para o gene laranja apresentarão as cores tanto preta, quanto laranja. Então, nas células em que o cromossomo inativado é o dominante para a cor laranja, a cor preta pode se expressar, resultando em tufos de pelos pretos, de modo que, em células em que o cromossomo inativado é o recessivo, a laranja se sobrepõe, originando tufos de pelos laranja. Isso torna a fêmea um mosaico de células (Pazza \& Kavalco, 2015), como é possível observar na Figura 4.

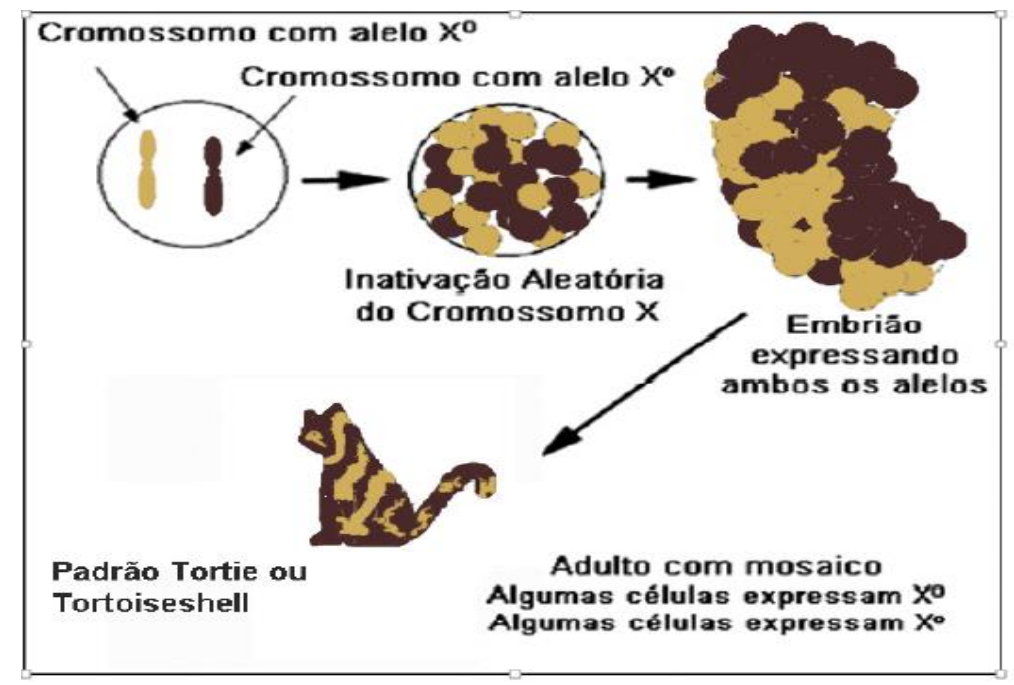

Figura 4. Exemplo do mecanismo de inativação do $X$ e, consequentemente, mosaico de células em um gato tortoiseshell. Fonte: Pazza \& Kavalco (2015).

O mosaicismo está incluído entre uma das principais consequências clínicas e genéticas do fenômeno de inativação do $\mathrm{X}$, mas esse tipo de mosaicismo não pode ser confundido com o mosaicismo resultante de uma alteração genética (Borges-Osório \& Robinson, 2013).

\section{Genética da pelagem de felinos domésticos cálico e tortoiseshell}

Gatos domésticos apresentam em seu conjunto cromossômico diploide normal 18 pares de cromossomos autossômicos, e um par de cromossomos sexuais ( $\mathrm{X}$ e $\mathrm{Y}$ ), sendo estes responsáveis pela composição genética e transmissão de fenótipo (Pontius et al., 2007). Então, em gatas, um óvulo com 19 cromossomos será fecundado por um espermatozoide com 19 cromossomos, resultando em filhotes diploides com 38 cromossomos, que se encontram dispostos com algumas proteínas. Quando ocorre a formação dos gametas, tanto masculinos (espermatozoides), como femininos (óvulos), esse número de cromossomos diminui, de modo que cada genitor doe metade do seu conjunto diploide (Pazza \& Kavalco, 2015). Dentre os 19 pares de cromossomos pertencentes ao gato, o sexo é determinado por um desses pares, chamados cromossomos sexuais, ou alossomos; os demais 18 pares são conhecidos como cromossomos autossomos (Pazza \& Kavalco, 2015).

Dentre as inúmeras colorações de pelagem de gatos, as pelagens tortoiseshell (Figura 5) e cálico (Figura 6), em que é possível observar as cores laranja e preto em mosaico, estão entre as mais fascinantes. Em 1904, apenas quatro anos após a descoberta dos conceitos de dominante e recessivo da herança mendeliana, o fenômeno da pelagem de gatos tortoiseshell e cálico foi o primeiro exemplo a ser utilizado para a explicação desses conceitos (Doncaster, 1904; Nicholas, 2010).

A determinação das cores de pêlos, pele e olhos se dão pela presença de um pigmento denominado melanina, que é depositado nos fios dos pelos e variam em forma e tamanho, características que influenciam diretamente na variedade de cores. Existem duas variações da melanina, a eumelanina, que é determinada por um gene autossômico (B), e é responsável pela produção da cor preta; e a feomelanina, determinada por um gene presente no cromossomo X, que produz a cor laranja. Gatos possuem uma particularidade em relação à eumelanina e feomelanina. Existem, em gatos, os alelos laranja e não laranja $(\mathrm{O} / \mathrm{o})$. O alelo recessivo não laranja (o), permite a expressão do gene $\mathrm{B}$ (preto), ao contrário do alelo dominante laranja (O), que é epistático em relação ao gene $\mathrm{B}$, impedindo a expressão da cor preta (Pazza \& Kavalco, 2015). 


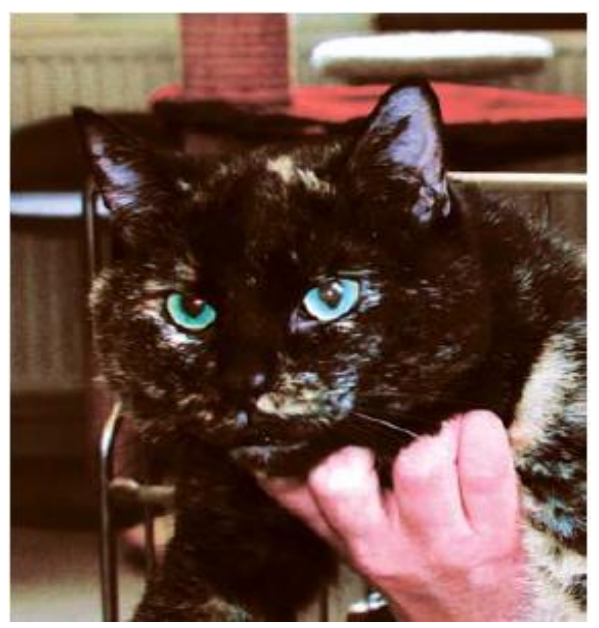

Figura 5. Pelagem tortoiseshell. Fonte: Pedersen et al. (2014).

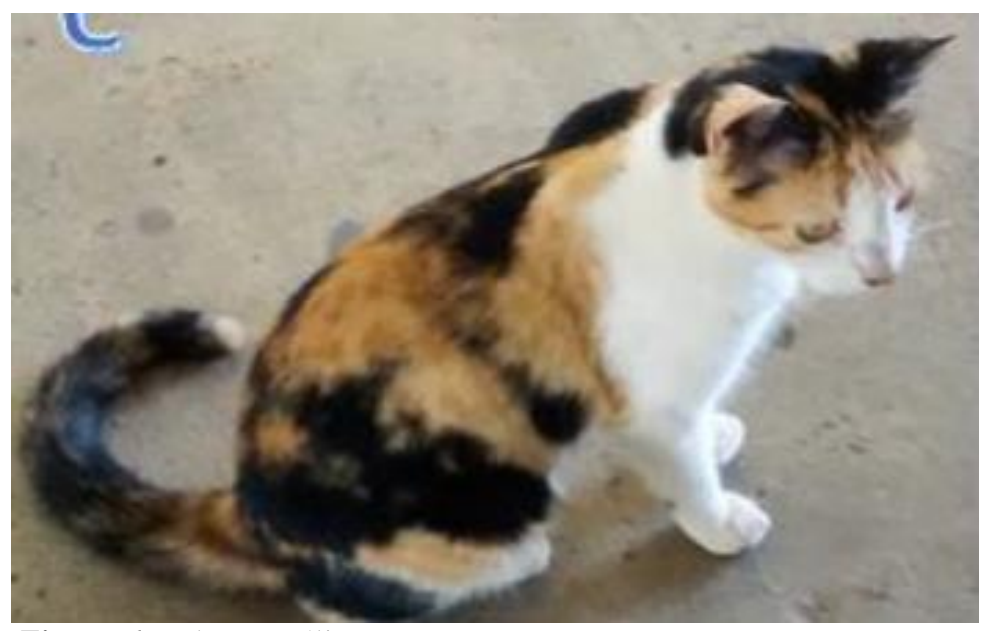

Figura 6. Pelagem cálico.

Fonte: Vargas et al. (2017).

A cor do pelo laranja é expressa pelo alelo (O), que por sua vez, inibe a produção do pigmento preto, e está ligado ao cromossomo X e o não laranja é determinado pelo (o), em que permite a expressão da cor preta. Quando o gato é cálico, possui também a cor branca, que é expressa pelo alelo white spotting e está presente em um cromossomo autossômico (Nicholas, 2010).

No entanto, é importante destacar que a presença ou ausência da melanina depende do alelo C. O alelo $\mathrm{C}$ dominante permite que a tirosina seja convertida em um produto intermediário, que por sua vez, é necessário para a produção de melanina. Então, se o gato possuir o genótipo CC ou Cc, a tirosina será convertida nesse produto intermediário e o gato poderá apresentar cor. Porém, se o genótipo do gato for cc, não haverá produção de melanina, logo, ele será albino (Figura 7). Na produção do produto intermediário em um gato $\mathrm{CC}$ ou $\mathrm{Cc}$, o gene $\mathrm{B}$ poderá produzir um gato preto, dependendo do genótipo do gene O, poderá ser laranja, ou tortoiseshell/cálico (Pazza \& Kavalco, 2015).

\section{Genes relacionados coma síntese de Melanina}

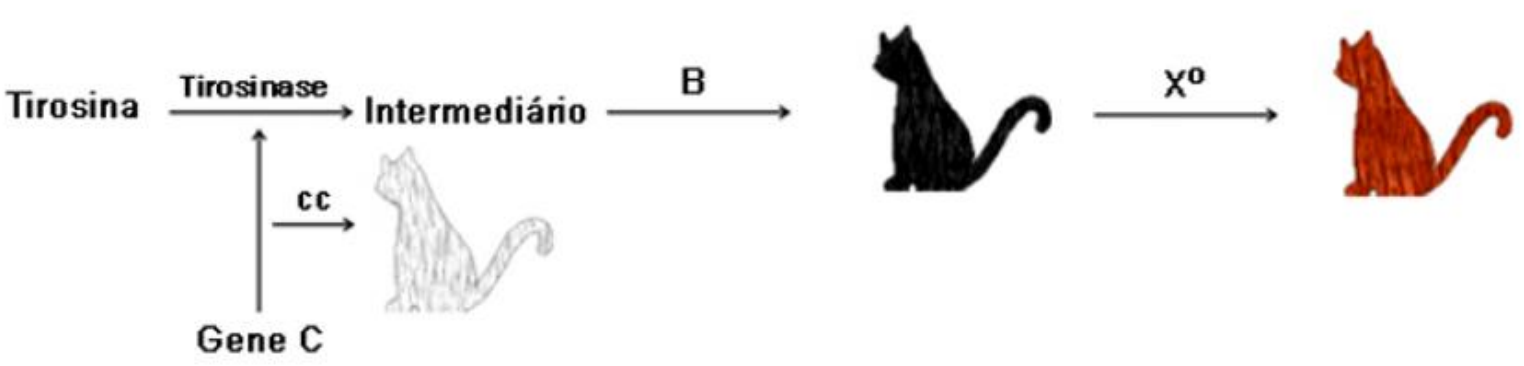

Figura 7. Ação do gene C sob a síntese de melanina. Fonte: Pazza \& Kavalco (2015).

Em muitos relatos, é possível observar que os termos cálico e tortoiseshell são mencionados como sinônimos. Embora esses padrões de pelagem não sejam iguais em sua distribuição de cores; isso não afeta estudos científicos, pois a forma que as cores se apresentam ao longo do corpo do animal não determina alterações genéticas; e a presença da cor branca no padrão cálico é herdada de forma isolada, ou seja, de um cromossomo autossômico (Centerwall \& Benirschke, 1973). Em gatos, a pelagem tortoiseshell apresenta a predominância de pelos pretos mesclados com pelos laranjas ao longo de todo o corpo; já na pelagem cálico, essas três cores se apresentam independentes, com predominância da cor branca (Costa et al., 2017).

A cor laranja varia entre creme, amarelo ou laranja escuro. O preto, muitas vezes denominado por inúmeras literaturas, como não laranja, também pode variar entre cinza, marrom, azul ou malhado, e embora apenas a coloração preta seja padrão para as pelagens tortoiseshell e cálico, a presença de outras variantes também é válida quando se trata de questões genéticas (Centerwall \& Benirschke, 1973). O 
marcador de coloração laranja (Orange) está ligado ao sexo, e possui diferentes formas de expressão. A forma heterozigota $(\mathrm{O} / \mathrm{o})$ do tipo tortoiseshell é uma das expressões desse marcador, bem como a forma também heterozigota $(\mathrm{O} / \mathrm{o})$ do tipo cálico, que possui duas variações, sendo a primeira, a expressão das três cores (laranja, preto e branco) em manto, e na segunda, o preto se mostra mesclado com um cinzento. Essas variações de pelagens, fisiologicamente, somente as fêmeas portam (Vargas et al., 2017).

O fator de pontuação branca (white spotting factor), gene dominante representado pela letra $S$, produz pontuações brancas no animal, ou seja, gatos que possuem o alelo "S" dominante, podem ter uma ou várias manchas brancas, pequenas ou grandes, ou até mesmo quase todo o corpo branco. Os melanoblastos, células precursoras de pigmentação, são responsáveis pela determinação desse padrão de manchas. Então, conclui-se que, fêmeas que possuam o gene fator de pontuação branca dominante (S), que sejam heterozigotas para o alelo laranja (O/o) e homozigota para o padrão sólido (a/a) apresentam porções de pelos bem definidas de cor branca, laranja e preto, padrão conhecido como cálico, e popularmente denominado tricolor (Pazza \& Kavalco, 2015).

Machos "normais" não apresentam essas colorações de pelagens características, por apresentarem apenas um cromossomo X. Logo, em relação à expressão de cores, os machos só podem expressar os fenótipos para as cores brancas, pretas, laranjas, brancas e as pretas ou brancas e laranjas (Costa et al., 2017). Assim, gatos machos que possuem pelagem cálico ou tortoiseshell são portadores de alguma desordem genética. Centerwall \& Benirschke (1973) relataram que gatos machos tortoiseshell e cálico são consideravelmente raros, e que é comum ouvir pessoas afirmando que apenas gatas fêmeas possuíam essa pelagem. Então, poucas pessoas sabiam que essa pelagem podia ser expressa em machos, ainda que raramente e decorrente de anomalias cromossômicas.

\section{Princípios básicos das anomalias cromossômicas}

A mutação consiste em alteração do material genético, envolvendo estrutura ou número, podendo ser súbita ou herdável, e acarreta mudanças no fenótipo do indivíduo. Mutação é o nome dado a qualquer mudança na sequência de nucleotídeos do DNA da célula, ou mesmo alteração em algum cromossomo (Junqueira \& Carneiro, 1997). Existem dois tipos de mutações, sendo eles mutações gênicas ou cromossômicas. As mutações gênicas envolvem alterações nos pares de base do DNA, podendo haver substituição, adição, ou perda de algum par de bases. As mutações cromossômicas podem ser estruturais ou numéricas. As mutações cromossômicas envolvem alterações em larga escala, envolvendo não só um gene, como ocorre nas mutações gênicas, mas inúmeros genes presentes em regiões dos cromossomos (Borges-Osório \& Robinson, 2013; Griffiths et al., 2008).

As anomalias cromossômicas são desordens que resultam de quantidade maior ou menor de material genético, ou de alterações estruturais. As mutações cromossômicas estruturais modificam a estrutura dos cromossomos, e as mutações numéricas envolvem alterações em seu número. Normalmente, essas mutações são denominadas anomalias cromossômicas (Borges-Osório \& Robinson, 2013; EsparzaGarcía et al., 2017).

As modificações que envolvem números de cromossomos podem ser distinguidas em euploidia, em que ocorrem mudanças no conjunto inteiro dos cromossomos, ou aneuploidia, em que as mudanças ocorrem apenas em partes do conjunto cromossômico (Griffiths et al., 2008).

Aneuploidia é o nome dado ao cariótipo que apresenta pequeno número de cromossomos ausentes ou extras, ao passo que, na poliploidia, há mais de dois conjuntos cromossômicos extras. Aneuploidia é uma categoria de anomalias cromossômicas que resulta em número de cromossomos anormal. É denominada de acordo com o número de cromossomos envolvidos na alteração. O organismo diploide aneuploide $2 \mathrm{n}+1$ é denominado trissômico, $2 \mathrm{n}-1$ é monossômico, $2 \mathrm{n}-2$ é nulissômico, pois o "-2" representa a perda dos dois homólogos. A maioria das aneuploidias é o resultado de não disjunção meiótica ou mitótica. Disjunção é o termo utilizado para designar a segregação normal de cromossomos homólogos, ou cromátides para polos opostos, e a falha em algum desses processos é denominada não disjunção (Griffiths et al., 2008). Essas alterações genéticas podem ocorrer de forma natural ou induzida, sob a ação de substâncias mutagênicas como radiações ionizante ou ultravioleta, que podem resultar em erros no momento da substituição das bases nitrogenadas, ou promover uma alteração na estrutura ou número de cromossomos (Veasey et al., 2011). 
As mutações podem ocorrer de duas formas, sendo elas somáticas ou germinativas. Mutações somáticas ocorrem em qualquer célula que não seja formadora de gametas, ao passo que, as mutações germinativas são provenientes de células germinativas, podendo passar de geração em geração (Moore, 1986).

\section{Anomalias cromossômicas envolvidas na pelagem de gatos domésticos machos tortoiseshell e cálico}

Gatos machos tortoiseshell ou cálico, normalmente são resultados de anomalias cromossômicas, dentre as quais se destacam a Síndrome de Klinefelter como a que ocorre na maioria dos casos, e resulta em um cariótipo 39, XXY; ocorre mais comumente por não disjunção meiótica (Hageltorn \& Gustavsson, 1981; Hartwell et al., 2008; Leaman et al., 1999; Nicholas, 2010). O processo de não disjunção cromossômica se dá devido a uma falha que ocorre no momento em que os cromossomos homólogos, na meiose, ou as cromátides irmãs, na mitose, precisam se separar de forma apropriada para os polos opostos da célula (Costa et al., 2017). Outra anomalia envolvida na presença dessa pelagem em gatos machos é o mosaicismo, que normalmente promove um cariótipo 38, XX/39, XXY (Vella et al., 1999).

Casos de quimerismo também são possíveis e acontecem durante uma gestação gemelar. Ocorre a fusão dos córions dos embriões, resultando em anastomose dos vasos, e posteriormente troca de células hematopoiéticas, que por sua vez, permanecem ativas pelo resto da vida do animal. É outro tipo de alteração genética que pode envolver gatos machos tortoiseshell ou cálico. Gatos denominados quimeras já foram descritos apresentando o cariótipo 38,XY/38XY, 38,XX/38,XY (Costa et al., 2017).

Dentre os principais sinais clínicos que gatos machos tortoiseshell ou cálico destacam-se aparência feminina, urina com cheiro característico forte e infertilidade. Outros sinais clínicos que gatos machos tortoiseshell normalmente envolvem um menor desenvolvimento corpóreo, criptorquidismo, aparência de fêmea, e volume testicular pequeno (Centerwall \& Benirschke, 1973; Costa et al., 2017; Pedersen et al., 2014). Foi desenvolvido um estudo com 25 gatos machos que apresentavam pelagens tortoiseshell ou cálico, e os animais foram submetidos a exames clínicos e físicos. Quase todos eles apresentaram esterilidade, e alguns apresentaram alterações testiculares, como tamanho reduzido. Posteriormente foram submetidos à análise citogenética, em que foram encontradas diferentes anomalias cromossômicas, como quimerismo, moisacismo, aneuploidia e poliploidia (Centerwall \& Benirschke, 1973; Costa et al., 2017). Em um estudo realizado entre 1990 a 1997 no Reino Unido, foram distribuídos questionários em inúmeras clínicas veterinárias, com o intuito de analisar os animais levados a essas clínicas. Com a resposta de 393 delas e informações sobre 9.816 gatos, sendo eles, 4.598 machos, apenas 20 possuíam pelagem tortoiseshell. Foi realizado exame citogenético em 11 deles, e seis apresentavam quimerismo $(38, \mathrm{XX} / 38, \mathrm{XY})$, dois aneuploidia $(39, \mathrm{XXY})$, dois cariótipo de fêmea $(38, \mathrm{XX})$, e um cariótipo de macho normal (38,XY) (Leaman et al., 1999). Em um outro estudo, que também realizou exame cariotípico, envolveu a análise de quatro gatos machos com pelagem tortoiseshell, dois deles apresentaram cariótipo aneuploide (39,XXY), um quimerismo $(38, \mathrm{XX} / 38, \mathrm{XY})$, e um cariótipo de macho normal (Costa et al., 2017). Já foram relatados também casos de $S R Y$-positivo na Polônia, também chamado de transtorno testicular do desenvolvimento sexual XX, que tem como causa a translocação de um fragmento do cromossomo sexual Y, portador do gene $S R Y$, no cromossomo X durante a meiose paterna. Um caso como esse foi descrito pela primeira vez em um gato macho de pelagem tortoiseshell que apresentava pênis rudimentar e ausência de escroto (Szczerbal et al., 2015). É importante ressaltar que as pelagens tortoiseshell e cálico em gatos machos podem ser utilizadas como marcadores eficientes de suspeita primária para anomalias cromossômicas, e, consequentemente, reprodutivas (Costa et al., 2017).

\section{Síndrome de Klinefelter}

O cromossomo Y é fundamental na determinação sexual de mamíferos machos. No entanto, em casos de anomalias cromossômicas como a Síndrome de Klinefelter, durante a divisão celular, ocorre uma falha, resultando, em machos, um cromossomo X extra (McElreavey \& Fellous, 1999; Wistuba et al., 2007). Assim, a Síndrome de Klinefelter é uma aberração cromossômica resultante da falha da segregação dos cromossomos sexuais durante a meiose (Lanfranco et al., 2004). A Síndrome de Klinefelter foi inicialmente descrita por Harry F. Klinefelter em 1942. As características apresentadas foram pequenos testículos, ausência de espermatogênese, as funções das células de Leydig mostraramse de normais a moderadamente reduzidas, e aumento da secreção do Hormônio Folículo Estimulante 
(FSH). Em 1959 houve a descoberta de que essa desordem havia sido causada pela presença de um cromossomo X a mais (Jacobs \& Strong, 1959; Klinefelter Junior et al., 1942).

De início, rapazes entram na puberdade com produção de testosterona em níveis normais, que logo depois caem drasticamente, evoluindo para um hipogonadismo. As características fenotípicas só se tornam evidentes após a puberdade (Okolie et al., 2017; Wikström \& Dunkel, 2008). A Síndrome de Klinefelter é uma poliploidia cromossômica em que, na maioria dos casos, os homens são inférteis, têm tamanho reduzido dos testículos e redução da produção de andrógeno. A falha dos espermatozoides ligada à infertilidade masculina tem como apresentações mais comuns, oligozoospermia ou azoospermia. A Síndrome de Klinefelter é a doença genética que mais causa essa disfunção (Groth et al., 2013; Röpke \& Tüttelmann, 2017). Na maioria dos casos, a Síndrome de Klinefelter é diagnosticada tardiamente, ou seja, quando as características fenotípicas começam a se manifestar. Os conhecimentos sobre essa anomalia ainda não foram completamente elucidados, em especial os mecanismos prejudiciais que o cromossomo X extra pode vir a acarretar ao homem (Wistuba, 2010; Wistuba et al., 2007).

Animais também são acometidos pela Síndrome de Klinefelter. Foram relatados casos em bovinos, cavalos, porcos, ovelhas, cães e gatos. Animais com Síndrome de Klinefelter apresentam, normalmente, esterilidade; porém, na maioria dos animais, é uma síndrome que só é detectável com a realização do cariótipo, por não apresentar características ou sinais muito expressivos, com exceção do gato, que apresenta as pelagens tortoiseshell ou cálico (Costa et al., 2017).

Já foi desenvolvido em Upsália um estudo em 10 gatos machos que apresentavam distúrbios reprodutivos. Com o intuito de observar se os animais possuíam dois cromossomos sexuais X a partir da presença da cromatina positiva, os gatos foram submetidos a esfregaço de mucosa, em que dois dos 10 gatos apresentaram dois cromossomos sexuais X, sendo um deles de pelagem tortoiseshell (Axnér et al., 1996).

Costa et al. (2017) relataram um caso de um gato macho com pelagem tortoiseshell que, submetido ao exame físico em uma clínica veterinária, apresentou condições gerais de saúde normais, e conformações de corpo e musculatura também. No entanto, ao realizar o exame físico dos testículos, eles se mostraram reduzidos, de acordo com a idade do animal, bem como pênis, espículas e coroa peniana também diminuídos. Ao ser submetido ao exame de cariótipo, confirmou-se a presença da Síndrome de Klinefelter, em que o gato apresentou um cariótipo 39,XXY.

Distúrbios apresentados na determinação do sexo geralmente são de fácil identificação e posterior diagnóstico, quando o animal apresenta genitais hermafroditas ou características diferentes às do seu sexo. Levando em conta essas observações, é difícil diagnosticar um animal com inversão completa do gênero, com falta de traços bissexuais fenotípicos, junto a características de desordens reprodutivas. Em casos de falha reprodutiva, é sempre bom considerar desordens genéticas como possíveis causas e manter-se atualizado sobre as técnicas de identificação (Christensen, 2012; Meyers-Wallen, 2012; Yimer \& Rosnina, 2014). Já foram realizados exames histológicos com tecido testicular de um gato macho tortoiseshell em Copenhague para verificação de infertilidade após confirmação de cariótipo $39, \mathrm{XXY}$. Foi realizada a análise de tecido testicular que, embora tenham sido observadas células de Sertoli remanescentes, não havia células espermatogênicas, também sendo observada degeneração dos túbulos seminíferos, caracterizando casos clássicos de gatos machos de pelagem tortoiseshell (Pedersen et al., 2014). Foram realizadas em um gato macho tortoiseshell com três anos de idade, técnicas de cultura de fibroblastos e análises histológicas, e a biópsia dos testículos demonstrou degeneração dos túbulos, hiperplasia do tecido intersticial, e ausência de células germinativas. Demonstrou-se um cariótipo 39,XXY (Pedersen et al., 2014).

O diagnóstico é baseado na identificação histopatológica do cromossomo sexual, gonadal e trato reprodutivo, e descrição interna e externa da morfologia genital. A identificação de desordens cromossômicas em gatos é de ocorrência rara. Os casos descritos são 39 XXY ou 38 XX, destacanddo os gatos machos de pelagem tortoiseshell e cálico. Em casos $S R Y$, os gatos domésticos geralmente apresentam características fenotípicas hermafroditas, bem como outras desordens (Leaman et al., 1999; Long, 1999). Pode-se ser demonstrada fertilidade em ambos os animais. Posteriormente, foi realizado exame cariotípico. Por meio da progênie, detectaram que os dois gatos estavam transmitindo os dois alelos no lócus ligado ao cromossomo X, porém, em frequências diferentes, demonstrando serem animais mosaicos, ou seja, possuíam duas linhagens de células distintas, mas de mesma origem (Costa et al., 2017). 
Em 2016 foi publicado um estudo de um gato da raça Bengal, com 23 meses de idade que foi encaminhado a uma clínica veterinária em Berna, na Suíça. O animal apresentava problemas comportamentais, criptorquidia e um órgão intra-abdominal desconhecido. Ao exame de ultrassonografia e tomografia computadorizada, foram observadas duas estruturas tubulares repletas de líquido, dorsolaterais à concluir que os princípios e mecanismos envolvidos na influência de um cromossomo $\mathrm{X}$ a mais em machos são semelhantes em humanos e animais, influenciando, de forma similar, o fenótipo masculino. Essa desordem pode estar ligada à incapacidade do macho em lidar com a expressão gênica ligada ao X (Wistuba, 2010; Wistuba et al., 2007).

O cariótipo de um indivíduo que possui a Síndrome de Klinefelter não se apresenta de forma homogênea, e na maioria dos casos pode ser visto na forma de um mosaico (Lanfranco et al., 2004).

\section{Mosaicismo}

No mosaicismo encontram-se presentes mais de uma população de células no organismo, sendo essas populações de células de mesma origem (Griffiths et al., 2008). Nessa alteração ocorre a não disjunção nas primeiras divisões mitóticas, após a formação do zigoto, o que resulta na presença de duas linhagens celulares diferentes em um mesmo indivíduo. Essa desordem é de causa desconhecida (Borges-Osório \& Robinson, 2013).

Em 1984, dois gatos machos de pelagem tortoiseshell foram submetidos a exames físicos e clínicos, em que foi demexiga e conectadas à uretra pélvica. $\mathrm{O}$ gato foi submetido à castração e os órgãos tubulares foram removidos cirurgicamente e posteriormente submetidos à análise histológica, em que foram identificados ductos de Müller remanescentes. Os testículos se encontravam hipoplásicos e a análise citogenética revelou um cariótipo mosaico 37,X/38,XY (Balogh et al., 2015).

A presença do moisacismo junto de alguma síndrome cromossômica, como a Síndrome de Klinefelter, pode amenizar as características clínicas do paciente. Um exemplo a ser mencionado é que alguns pacientes que possuem a Síndrome de Turner ou de Klinefelter em mosaico podem ser férteis, diferente de pacientes que possuem apenas a linhagem celular da síndrome. Inicialmente, o mosaicismo é difícil de ser diagnosticado a partir de sinais clínicos, sendo importante a realização de análise citogenética (Paskulin et al., 2011).

\section{Quimerismo}

No quimerismo, há a presença de duas ou mais linhagens de células em um mesmo indivíduo, sendo essas linhagens geneticamente diferentes, originadas de mais de um zigoto. Há dois tipos de quimera humano, sendo eles quimera dispérmica e quimera sanguínea (Borges-Osório \& Robinson, 2013). Na quimera dispérmica ocorre fertilização dupla, em que há a fecundação de dois óvulos por dois espermatozoides, formando dois zigotos que se fundem e formam um embrião. Se os dois zigotos forem de sexos diferentes, o embrião quimérico pode desenvolver um indivíduo com hermafroditismo verdadeiro e cariótipo XX/XY. Quimerismo sanguíneo ocorre quando há a troca placentária de células entre gêmeos dizigóticos, no útero. Um exemplo a ser citado é quando um cogêmeo possui grupo sanguíneo $\mathrm{B}$, e o outro $\mathrm{A}$. Se as células do primeiro cogêmeo passarem para a circulação do segundo, este desenvolverá os antígenos A e B, resultando em um indivíduo quimera sanguíneo (Borges-Osório \& Robinson, 2013).

O primeiro caso de quimera humana foi descrito em 1953, e envolvia uma mulher britânica que supostamente carregava tipos diferentes de sangue. $\mathrm{O}$ resultado dos exames comprovou que ela apresentava os tipos sanguíneos A e O. Após a clínica realizar o teste novamente, já que o resultado parecia ser impossível, o novo exame foi confirmado de acordo com o antigo: a mulher possuía os dois tipos sanguíneos (A e O) (Granzen, 2014). O médico responsável pelos procedimentos pertinentes ao exame lembrou que já haviam sido relatados casos de gêmeos que apresentavam sangue misto, fator resultante da gestação, e ao perguntar da paciente se a mesma possuía algum irmão gêmeo, a mulher confirmou, ressaltando que o irmão havia falecido meses após o nascimento. O médico realizou um outro exame, mas desta vez com a saliva da paciente, que resultou em sangue do tipo O. O médico concluiu, então, que a mulher possuía originalmente sangue $\mathrm{O}$, e que o tipo $\mathrm{A}$ foi recebido de seu irmão gêmeo, confirmando o primeiro caso de quimera humana (Granzen, 2014). 
Animais com quimerismo também apresentam duas populações de leucócitos distintas por seus cromossomos sexuais, apresentando cariótipo $2 \mathrm{n}=38, \mathrm{XX} / 38, \mathrm{XY}$ (Costa et al., 2017). Em bovinos, quando ocorre o nascimento de dois bezerros de sexos opostos, a fêmea normalmente apresenta genitália ambígua, e atualmente, acredita-se que isso ocorre por quimerismo gonadal nas fêmeas dos bezerros, o que é conhecido como freemartin (Borges-Osório \& Robinson, 2013).

Já foram relatados casos em Nova Iorque de gatos $38, \mathrm{XX} / 38, \mathrm{XY}$ quimeras com pelos pretos e laranja que eram fenotipicamente machos. Alguns deles possuíam testículos e ovários desenvolvidos. Em alguns casos foi relatada fertilidade ou espermatogênese (Meyers-Wallen, 2012). Centerwall \& Benirschke (1973), ao realizarem exames cariotípicos em 25 gatos machos de pelagem tortoiseshell ou cálico, três gatos apresentaram cariótipo de macho normal (XY). Eles então concluíram esses gatos se tratavam de animais quiméricos resultantes da fusão de dois embriões do mesmo sexo.

O quimerismo pode ser de ocorrência natural ou artificial. A forma natural pode passar despercebida por toda a vida do indivíduo. A forma artificial decorre de intervenções médicas e científicas (Ramos \& Cunha, 2016). Normalmente, o quimerismo não é diagnosticado, pois depende de alguns sinais clínicos ou características sugestivas da anomalia para a realização do exame. Os sintomas físicos, embora sejam raros, podem ser verificado para detecção do quimerismo, como ambiguidade genital, hermafroditismo, pele com coloração desigual ou cores distintas dos olhos, mas se o indivíduo não apresenta quaisquer sintomas, é difícil detectar a condição genética (Ramos \& Cunha, 2016).

Em um estudo realizado em quatro gatos machos de pelagem tortoiseshell, um desses animais apresentou quimerismo $(38, \mathrm{XX} / 38, \mathrm{XY})$. Esse gato foi submetido a análise histológica testicular, e a espermatogênese só estava presente em alguns túbulos seminíferos. Então, é possível observar que em gatos machos a pelagem de coloração tortoiseshell pode ser indicativo de um animal quimera (Costa et al., 2017).

\section{Citogenética}

A citogenética é o termo utilizado para designar qualquer estudo voltado ao cromossomo, seja ele isolado ou em conjunto, condensado ou distendido, no que se refere à sua forma, organização, função e replicação, bem como variação e evolução (Guerra, 1988). A citogenética tem sido utilizada como ferramenta importante no entendimento da diversidade genética, bem como taxonomia de espécies e afins. Também é utilizada nas áreas de medicina, em que o número de malformações congênitas, desvios metabólicos, displasias esqueléticas, anomalias cromossômicas e outros distúrbios genéticos crescem cada vez mais (Guerra, 1988).

Na primeira metade do século XX foram desenvolvidos os primeiros passos para o desenvolvimento do cariótipo. Logo após o entendimento da ação da colchicina e do tratamento hipotônico das células, foi estabelecida a determinação do número correto de cromossomos humanos (46) pela contagem de células somáticas. A partir dessas descobertas, passou a ser possível identificar as anomalias cromossômicas. Foi descrita então, em 1959, a primeira trissomia de cromossomos autossômicos, conhecida como Síndrome de Down (Lejeune, 1959; Tjio \& Levan, 1956; Trevisan et al., 2014).

O progresso de identificação dos cromossomos deu-se a partir de uma gama de estudos ocorridos entre os anos 1968 e 1969, que tiveram como princípio a utilização de corantes com afinidade com o DNA, como orceína e giemsa, que passaram a auxiliar na identificação de cromossomos. Essa coloração só identificava as anomalias cromossômicas numéricas, pois as aberrações estruturais dificilmente podiam ser observadas, ou eram impossíveis de serem detectadas (Maluf \& Riegel, 2011).

O cariótipo pode ser representado nas formas de idiograma ou cariograma. O idiograma consiste na representação esquemática do cariótipo, em que são utilizados valores médios da posição de cada centrômero, bem como tamanho de cada cromossomo do conjunto haploide. É possível então obter os valores a partir da medição realizada nos cromossomos de várias células de um indivíduo, ou mesmo de uma espécie. O cariograma constrói-se a partir de um desenho detalhado de uma metáfase, em que os cromossomos se mostram corados e separados, pois os cromossomos se condensam consideravelmente no período da mitose, fazendo com que, nessa fase, se tornem visíveis ao microscópio óptico (Figura 8). Normalmente, a técnica mais acessível e menos invasiva é a que envolve a cultura de células a partir da colheita de sangue periférico. Posteriormente, todos esses cromossomos são recortados e os pares homólogos são emparelhados e enumerados de acordo com a ordem de cada espécie (Figura 9) (Guerra, 1988; Junqueira \& Carneiro, 1997). 


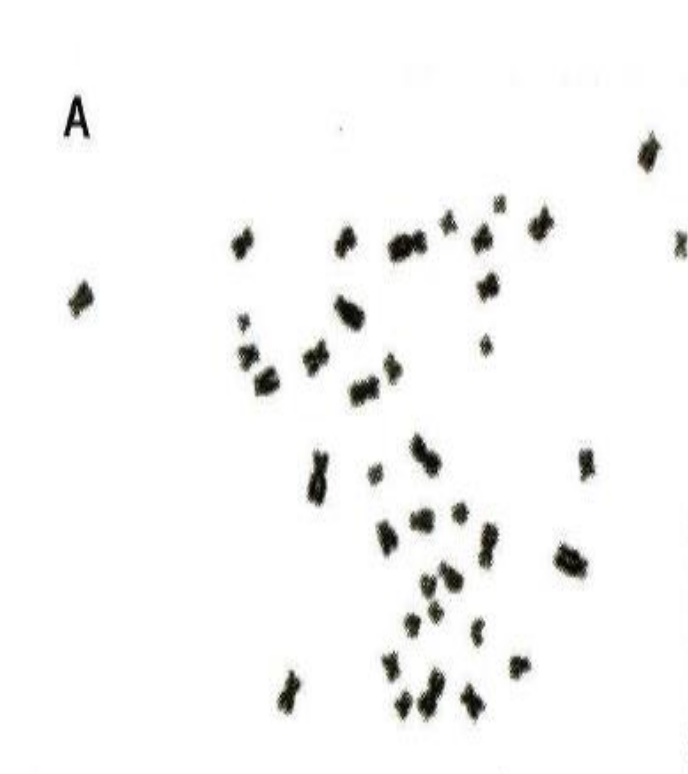

Figura 8. Célula de um gato em metáfase mitótica Fonte: Costa et al. (2017).

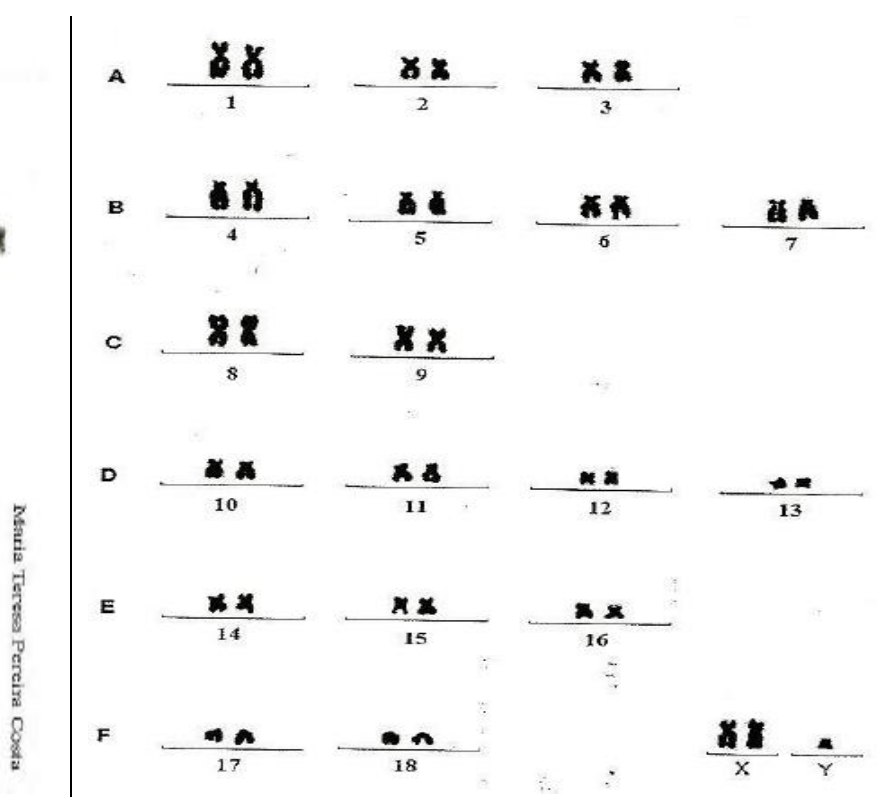

Figura 9. Exame cariotípico de um gato macho com Síndrome de Klinefelter. Fonte: Costa et al. (2017).

No cariótipo, os pares de autossomos são numerados de forma decrescente em relação ao seu tamanho, de um a 22. Os cromossomos sexuais são designados por X e Y. Os pares cromossômicos são divididos em sete grupos que são caracterizados da letra A a G (Kasahara, 2003). Pesquisadores elaboraram estudos no intuito de aperfeiçoar o exame. Foram desenvolvidas técnicas de coloração longitudinal dos cromossomos, mais conhecidas como "bandeamento", e posteriormente técnicas de alta resolução cromossômica, resultando em um melhor reconhecimento diagnóstico das alterações cromossômicas (Caspersson et al., 1970; Trevisan et al., 2014).

Dentre as técnicas de diagnóstico mais específico, é possível destacar a Hibridização in situ fluorescente (FISH), a Reação em Cadeia da Polimerase (PCR), e as técnicas de bandeamento que tornaram possível a visualização de blocos de coloração diferenciadas, conhecidos como bandas (Chaves \& Nicolau, 2013; Esparza-García et al., 2017).

\section{Citogenética na medicina veterinária}

A citogenética veterinária é uma área que identifica as características genéticas normais ou anormais em animais. Como muitas das anomalias cromossômicas vêm acompanhadas de infertilidade, a área tem significativa importância econômica em algumas espécies animais. Em várias áreas da medicina clínica, a análise cromossômica tem sido melhorada exaustivamente e é utilizada em pequenos e grandes animais (Chaves \& Nicolau, 2013; Yimer \& Rosnina, 2014).

Devido à dificuldade de se desenvolver estudos experimentais sobre a Síndrome de Klinefelter em humanos por questões éticas, passaram a utilizar em ratos. A forma de diagnóstico utilizada para a detecção da anomalia dificultava as pesquisas, pois só era possível realizar as técnicas de identificação após a morte do animal. Posteriormente, foram desenvolvidas técnicas para identificação desses cromossomos, onde era possível realizar os exames a partir da biópsia da ponta da cauda dos animais, e, logo após isso, passaram a utilizar amostras de sangue periférico para cultura de leucócitos, sendo este último, um método menos invasivo (Lewejohann et al., 2009; Lue et al., 2005). Esse avanço citogenético proporcionou melhoras significativas, resultando em novas abordagens experimentais em modelos de ratos para melhor exploração dos mecanismos envolvidos na Síndrome de Klinefelter (Wistuba, 2010; Wistuba et al., 2007). Os estudos citogenéticos começaram a ser desenvolvidos nos gatos domésticos há mais de 50 anos, em consequência da ampliação significativa dos animais integrantes da família Felidae, resultando em um avanço de técnicas de cultivo celular para obtenção de amostras cromossômicas. Graças a esse avanço na citogenética veterinária, foi possível detectar características genéticas dessa família (Clavijo-Maldonado \& Ramírez-Benavides, 2011). 
Estudos obtidos com 10 gatos que apresentavam problemas reprodutivos foram realizados na Suécia a partir de esfregaço de mucosa bucal. Com o intuito de observar cromatina nuclear positiva, fator que é observado em indivíduos com dois cromossomos sexuais $\mathrm{X}$, o esfregaço foi analisado, e concluiu-se que dois gatos apresentaram anomalias cromossômicas, sendo um deles de pelagem tortoiseshell (Axnér et al., 1996).

\section{Exame de cariótipo no diagnóstico de anomalias cromossômicas em gatos de pelagens tortoiseshell ou cálica}

Com a descoberta do Corpúsculo de Barr em 1949, foram desenvolvidos os estudos específicos dos cromossomos X e Y, denominado sexo nuclear. Sendo eles a cromatina sexual do X ou cromatina sexual do Y. São técnicas que podem ser utilizadas em substituição ao cariótipo. A técnica consiste na utilização de vários tipos celulares em interfase, como células da mucosa oral ou vaginal, sedimento urinário, líquido amniótico, dentre outros (Borges-Osório \& Robinson, 2013).

A cromatina sexual do $\mathrm{X}$, também conhecida como Corpúsculo de Barr, aparece em células interfásicas de fêmeas de mamíferos, e corresponde a um dos cromossomos $\mathrm{X}$ inativado. Citologicamente, apresenta-se como uma massa corada, com forma plano-convexa, e aproximadamente um mícron de diâmetro, aderida à membrana celular. A cromatina sexual do $\mathrm{Y}$ também pode ser visualidade em células interfásicas, e corresponde à presença de ao menos um cromossomo Y. Normalmente é utilizada alguma coloração fluorescente, como a quinacrina, e a lâmina pode ser observada em microscópio de contraste de fase, em que o cromossomo $\mathrm{Y}$, quando presente, aparece como um ponto brilhante (Borges-Osório \& Robinson, 2013).

Exames cariotípicos vêm sendo largamente utilizados em gatos machos tortoiseshell ou cálico. Normalmente, para a realização do exame, os laboratórios solicitam uma amostra de $5 \mathrm{~mL}$ de sangue periférico em seringa previamente heparinizada. O exame é realizado a partir da cultura de linfócitos (Costa et al., 2017; Moorhead et al., 1960).

Em um relato de gato macho tortoiseshell, publicado em 2017, o protocolo realizado para a realização do cariótipo foi a transferência de 10 gotas de sangue total em um frasco com meio de cultura a 4,5 mL, $0,1 \mathrm{~mL}$ de fitohemaglutinina, penicilina/estreptomicina a $0,1 \mathrm{~mL}$, e $0,5 \mathrm{~mL}$ de soro bovino fetal. A amostra foi submetida à estufa por 72 horas a $38^{\circ} \mathrm{C}$. Com 71 horas e 30 minutos, $0,1 \mathrm{~mL}$ de colchicina $0,0016 \%$ foram adicionados. Posteriormente, foram coradas lâminas em solução de giemsa a $5 \%$ em tampão fosfato $0,06 \mathrm{M}, \mathrm{pH} 6,8$, por dois minutos, para a realização da análise. Vale destacar que, nesse estudo, as células analisadas se encontravam em metáfase mitótica, e em $100 \%$ das metáfases havia a presença do número diploide de 39 cromossomos, sendo eles dois cromossomos sexuais $\mathrm{X}$, e um cromossomo sexual Y, cariótipo característico da Síndrome de Klinefelter (Costa et al., 2017).

Também pode ser realizado o cariótipo de fibroblastos com biópsias da pele. O fragmento da pele é colocado em um frasco com meio de cultura para transporte e posteriormente transferido para uma placa de Petri pequena onde, por meio do bisturi são cortadas inúmeras vezes. O material obtido é semeado em frascos com meio de cultura e colocado em estufa e, ao final do crescimento das culturas, passa pelo mesmo processo que é realizado com o sangue (Paskulin et al., 2011).

\section{Conclusão}

As alterações genéticas que envolvem a presença das pelagens tortoiseshell ou cálico em gatos machos domésticos têm como consequência, normalmente, a presença de distúrbios reprodutivos, sendo os gatos os únicos animais a apresentarem essa pelagem característica como sinal clínico aparente de uma possível anomalia cromossômica. A citogenética em felinos ainda é limitada, porém é uma ferramenta importante na Medicina Veterinária, principalmente para a detecção de anomalias e/ou patogenias. Portanto, é importante que pesquisadores sejam estimulados a desenvolverem estudos científicos voltados à genética dessa pelagem presente em gatos machos, pois embora tenha sido descoberta há anos, é pouco conhecida e explorada.

\section{Referências bibliográficas}

Axnér, E., Ström, B., Linde-Forsberg, C., Gustavsson, I., Lindblad, K. \& Wallgren, M. (1996). Reproductive disorders in 10 domestic male cats. Journal of Small Animal Practice, 37(8):394-401. 
Balogh, O., Berger, A., Pieńkowska-Schelling, A., Willmitzer, F., Grest, P., Janett, F., . . Reichler, I. M. (2015). 37, X/38, XY Mosaicism in a Cryptorchid Bengal cat with Müllerian duct remnants. Sexual Development, 9(6):327-332.

Borges-Osório, M. R. \& Robinson, W. M. (2013). Genética Humana. Porto Alegre, Rio Grande do Sul, Brasil: Artmed.

Caspersson, T., Zech, L. \& Johansson, C. (1970). Differential binding of alkylating fluorochromes in human chromosomes. Experimental Cell Research, 60(3):315-319.

Centerwall, W. R. \& Benirschke, K. (1973). Male Tortoiseshell and Calico (TC) Cats: Animal models of sex chromosome mosaics, aneuploids, polyploids, and chimerics. Journal of Heredity, 64(5):272278.

Chaves, T. F. \& Nicolau, L. S. (2013). Citogenética \& cariotipagem humana. Revista Saúde e Desenvolvimento, 4(2):57-66.

Christensen, B. W. (2012). Disorders of sexual development in dogs and cats. Veterinary Clinics: Small Animal Practice, 42(3):515-526.

Clavijo-Maldonado, A. \& Ramírez-Benavides, G. F. (2011). Características cromosómicas de la familia Felidae. Veterinaria e Zootecnia, 5(1):87-95.

Costa, M. T. P., Lobo, R. R., Santiloni, V. \& Mota, L. S. L. S. (2017). Aneuplodia de cromossomos sexuais em gato de pelagem tortoiseshell-relato de caso. Clín. Vet., 22(126):40-44.

Doncaster, L. (1904). V.-Experiments in hybridization, with special reference to the effect of conditions on dominance. Philosophical Transactions of the Royal Society of London. Series B, Containing Papers of a Biological Character, 196(214-224):119-173.

Esparza-García, E., Cárdenas-Conejo, A., Huicochea-Montiel, J. C. \& Aráujo-Solís, M. A. (2017). Chromosomes, chromosomal abnormalities and diagnostic issues. Revista Mexicana de Pediatría, 84(1):30-39.

Granzen, R. R. (2014). The Human Chimera: Legal Problems Arising From Individuals with Multiple Types of DNA. Law School Student Scholarship, 1(1):1-27.

Graves, J. A. M. (1995). The evolution of mammalian sex chromosomes and the origin of sex determining genes. Philosophical Transactions of the Royal Society of London. Series B: Biological Sciences, 350(1333):305-312.

Griffiths, A., Wessler, S., Lewontin, R. \& Carroz, S. (2008). Introdução à genética. Rio de Janeiro, Brasil: Guanabara Koogan S.A.

Groth, K. A., Skakkebæk, A., Høst, C., Gravholt, C. H. \& Bojesen, A. (2013). Klinefelter syndromea clinical update. The Journal of Clinical Endocrinology \& Metabolism, 98(1):20-30.

Guerra, M. (1988). Introdução à citogenética geral. Rio de Janeiro, Brasil: Guanabara Koogan.

Hageltorn, M. \& Gustavsson, I. (1981). XXY-trisomy identified by banding techniques in a male tortoiseshell cat. Journal of Heredity, 72(2):132-134.

Hartwell, L., Hood, L., Goldberg, M., Reynolds, A. \& Silver, L. (2008). Genetics: From gene to genomes. New York, USA: McGraw Hill.

Jacobs, P. A. \& Strong, J. A. (1959). A case of human intersexuality having a possible XXY sexdetermining mechanism. Nature, 183(4657):302-303.

Junqueira, L. C. \& Carneiro, J. R. (1997). Biologia Celular e Molecular. Rio de Janeiro, Brasil: Guanabara Koogan.

Kasahara, S. (2003). Práticas de citogenética. Rio Claro, São Paulo, Brasil: Sociedade Brasileira de Genética.

Klinefelter Junior, H. F., Reifenstein Junior, E. C. \& Albright Junior, F. (1942). Syndrome characterized by gynecomastia, aspermatogenesis without A-Leydigism, and increased excretion of folliclestimulating hormone. The Journal of Clinical Endocrinology, 2(11):615-627.

Lanfranco, F., Kamischke, A., Zitzmann, M. \& Nieschlag, E. (2004). Klinefelter's syndrome. The Lancet, 364(9430):273-283. 
Leaman, T., Rowland, R. \& Long, S. E. (1999). Male tortoiseshell cats in the United Kingdom. Veterinary Record, 144(1):9-12.

Lejeune, J. (1959). Etude des chromosomes somatiques de neuf enfants mongoliens. Comptes Rendus Hebdomadaires des Séances de I'Académie des Sciences, 2481721-1722.

Lewejohann, L., Damm, O. S., Luetjens, C. M., Hämäläinen, T., Simoni, M., Nieschlag, E., .. . Wistuba, J. (2009). Impaired recognition memory in male mice with a supernumerary $\mathrm{X}$ chromosome. Physiology \& Behavior, 96(1):23-29.

Long, S. E. (1999). 38, XX/38, XY chromosome chimaerism in three feline siblings. UK: British Medical Journal Publishing Group.

Lue, Y., Jentsch, J. D., Wang, C., Rao, P. N., Sinha Hikim, A. P., Salameh, W. \& Swerdloff, R. S. (2005). XXY mice exhibit gonadal and behavioral phenotypes similar to Klinefelter syndrome. Endocrinology, 146(9):4148-4154.

Lyon, M. F. (1961). Gene action in the X-chromosome of the mouse (Mus musculus L.). Nature, 190(4773):372.

Maluf, S. W. \& Riegel, M. (2011). Citogenética humana. Porto Alegre, Rio Grande do Sul, Brasil: Artmed.

McElreavey, K. \& Fellous, M. (1999). Sex determination and the Y chromosome. American Journal of Medical Genetics, 89(4):176-185.

Meyers-Wallen, V. (2012). Gonadal and sex differentiation abnormalities of dogs and cats. Sexual Development, 6(1-3):46-60.

Moore, J. A. (1986). Science as a way of knowing — genetics. American Zoologist, 26(3):583-747.

Moorhead, P. S., Nowell, P. C., Mellman, W. J., Battips, D. M. \& Hungerford, D. A. (1960). Chromosome preparations of leukocytes cultured from human peripheral blood. Experimental Cell Research, 20(3):613-616.

Nicholas, F. W. (2010). Introdution to Veterinary Genetics. UK: Chichester: Willey-Blackwell.

Okolie, K., Perampalam, S., Barker, A. \& Nolan, C. J. (2017). A case of Klinefelter syndrome with hypersexual desire. Endocrinology, Diabetes \& Metabolism Case Reports, 2017(1):1-5.

Paskulin, G. A., Lorenzen, M. B., Rosa, R. F. M., Graziadio, C. \& Zen, P. R. G. (2011). Importância da análise cromossômica dos fibroblastos em casos suspeitos de mosaicismo: experiência de um serviço de Genética Clínica. Revista Paulista de Pediatria, 29(1):73-79.

Pazza, R. \& Kavalco, K. F. (2015). Uma pequena introdução à genética de felinos. Belo Horizonte, Minas Gerais, Brasil: Araucária Comunicação e Editora.

Pedersen, A. S., Berg, L. C., Almstrup, K. \& Thomsen, P. D. (2014). A tortoiseshell male cat: chromosome analysis and histologic examination of the testis. Cytogenetic and Genome Research, 142(2):107-111.

Pontius, J. U., Mullikin, J. C., Smith, D. R., Team, A. S., Lindblad-Toh, K., Gnerre, S., ... Neelam, B. (2007). Initial sequence and comparative analysis of the cat genome. Genome Research, 17(11):1675-1689.

Ramos, A. V. G. F. F. \& Cunha, L. R. B. (2016). Um outro eu: o caso das quimeras humanas. Revista de Bioética y Derecho, 38101-117.

Raven, P. H., Evert, R. F. \& Eichhorn, S. E. (1996). Biologia Vegetal. Rio de Janeiro, Brasil: Guanabara Koogan.

Röpke, A. \& Tüttelmann, F. (2017). Aberrations of the X chromosome as cause of male infertility. European Journal of Endocrinology, 177(5):R249-R259.

Rye, C., Wise, R., Jurukovski, V., Desaix, J., Choi, J. \& Avissar, Y. (2017). Biology. Houston, USA: OpenStax.

Szczerbal, I., Stachowiak, M., Dzimira, S., Sliwa, K. \& Switonski, M. (2015). The first case of 38, XX (SRY-positive) disorder of sex development in a cat. Molecular Cytogenetics, 8(22):1-5.

Tjio, J. H. \& Levan, A. (1956). The chromosome number of man. Hereditas, 42(1-2):1-6. 
Trevisan, P., Rosa, R. F. M., Koshiyama, D. B., Zen, T. D., Paskulin, G. A. \& Zen, P. R. G. (2014). Cardiopatias congênitas e cromossomopatias detectadas por meio do cariótipo. Revista Paulista de Pediatria, 32(2):262-271.

Vargas, L. A. C., Pérez, E. P. \& Mass, B. L. M. (2017). Estructura genética-poblacional de gatos domésticos (Felis catus), usando marcadores fenotípicos en Santa Marta, Colombia. Revista Logos, Ciencia \& Tecnología, 8(2):182-190.

Veasey, E. A., Piotto, F. A., Nascimento, W. F., Rodrigues, J. F., Mezette, T. F., Borges, A., . . Recchia, G. H. (2011). Processos evolutivos e a origem das plantas cultivadas. Ciência Rural, 41(7):12181228.

Vella, C., Shelton, L., McGonagle, J. \& Stanglein, T. (1999). Robinson's genetics for cat breeders and veterinarians. Burlingthon: Butterworth-Heinemann.

Wikström, A. M. \& Dunkel, L. (2008). Testicular function in Klinefelter syndrome. Hormone Research in Paediatrics, 69(6):317-326.

Wistuba, J. (2010). Animal models for Klinefelter's syndrome and their relevance for the clinic. MHR: Basic Science of Reproductive Medicine, 16(6):375-385.

Wistuba, J., Stukenborg, J.-B. \& Luetjens, C. M. (2007). Mammalian spermatogenesis. Functional Development and Embriology, 1(2):99-117.

Yimer, N. \& Rosnina, Y. (2014). Chromosomal anomalies and infertility in farm animals: A Review. Pertanika Journal of Tropical Agricultural Science, 37(1):1-18.

Recebido: 9 de junho, 2019.

Aprovado: 8 de julho, 2019.

Publicado: 5 de agosto, 2019.

Licenciamento: Este artigo é publicado na modalidade Acesso Aberto sob a licença Creative Commons Atribuição 4.0 (CC-BY 4.0), a qual permite uso irrestrito, distribuição, reprodução em qualquer meio, desde que o autor e a fonte sejam devidamente creditados. 